Т. О. Перцева, Л. Ю. Науменко, С. В. Захаров, О. О. Нефьодов, В. Ф. Шаторна, О. О. Нефьодова, О. В. Кузнецова, К. Л. Шамелашвілі Державний заклад «Дніпропетровська медична академія Міністерства охорони здоров'я України»

\title{
ПЕРШИЙ ДОСВІД ПІДГОТОВКИ ІНОЗЕМНИХ СТУДЕНТІВ ФРАНКОМОВНОЇ ФОРМИ НАВЧАННЯ У ДЕРЖАВНОМУ ЗАКЛАДІ «ДНІПРОПЕТРОВСЬКА МЕДИЧНА АКАДЕМІЯ МІНІСТЕРСТВА ОХОРОНИ ЗДОРОВ’Я УКРАЇНИ»
}

\section{T. O. Pertseva, L. Yu. Naumenko, S. V. Zakharov, O. O. Nefodov, V. F. Shatorna, O. O. Nefodova, O. V. Kuznetsova, K. L. Shamelashvili \\ Dnipropetrovsk Medical Academy \\ THE FIRST EXPERIENCE OF TRAINING OF FRENCH-SPEAKING STUDENTS IN STATE ESTABLISHMENT “DNIPROPETROVSK MEDICAL ACADEMY OF HEALTH MINISTRY OF UKRAINE”}

\begin{abstract}
Мета роботи - проаналізувати рівень та якість підготовки іноземних студентів франкомовної форми навчання у Державному закладі «Дніпропетровська медична академія Міністерства охорони здоров’я України».

Основна частина. Висвітлено різні аспекти підготовки іноземних громадян у вищій медичній школі на додипломному етапі. Наведено основні заходи щодо створення умов для вдосконалення системи підготовки іноземних громадян. Акцентовано увагу на франкомовному напрямі освітнього процесу кафедр першого курсу спеціальностей «Медицина» та «Стоматологія».

Висновок. Комплексна підготовка, а саме вивчення нової мови викладання, підготовка якісного навчально-методичного забезпечення та ефективна вмотивованість дозволили розпочати викладання у Дніпропетровській медичній академії французькою мовою.
\end{abstract}

Ключові слова: організація навчального процесу; франкомовне навчання; іноземні студенти.

The aim of the work - to analyze the level and quality of training of foreign students of the French-speaking form of study at the State Establishment "Dnipropetrovsk Medical Academy of Ministry of Health of Ukraine"

The main body. Different aspects of training of foreign citizens in the higher medical school for up to the diploma stage are highlighted. The main measures for creation of conditions for improvement of the system of training of foreign citizens are presented. The emphasis is on the French-speaking direction of the educational process of the first-year departments of the specialties "Medicine" and "Dentistry".

Conclusion. Comprehensive training, namely, the study of a new language of teaching, the training of quality teaching and methodological support and effective motivation allowed to start teaching in the Dnepropetrovsk Medical Academy in French.

Key words: organization of educational process; francophone education; foreign students.

Вступ. Одним із пріоритетних напрямів освітньої політики розвинутих країн світу є підготовка іноземних студентів. Причому реалізація цього напряму в багатьох державах спрямована, перш за все, на виконання стратегічних завдань, а саме підвищення міжнародного впливу через поширення своєї культури (зокрема мови) та підготовку інтелектуальної еліти для зарубіжних країн. Хоча і суто економічне завдання не можна назвати незначущим навіть для розвинутих держав. Україна як держава із великим потенціалом розвитку ринку освіти також включи-

(c) Т. О. Перцева, Л. Ю. Науменко, С. В. Захаров та ін. лася у процес розробки нових і вдосконалення вже існуючих послуг.

Мета роботи - проаналізувати рівень та якість підготовки іноземних студентів франкомовної форми навчання у Державному закладі «Дніпропетровська медична академія Міністерства охорони здоров’я України».

Основна частина. Державний заклад «Дніпропетровська медична академія Міністерства охорони здоров’я України» здійснює прийом та підготовку іноземних студентів з 1990 р. на підготовче відділення і з 1991 р. навчання на медичному та стома- 
тологічному факультетах за фахом: «Лікувальна справа», «Стоматологія», у 2008 р. - за фахом «Фармація», у 2009 р. - «Клінічна фармація», заочне навчання. 32003 р. розпочалася підготовка до викладання англійською мовою. За цей час було підготовлено 1054 лікарі для більш як 53 країн світу.

3 жовтня 2018 р. у Дніпропетровській медичній академії розпочалася підготовка іноземних громадян французькою мовою. Зазначимо, що цей новітній напрям освіти є першим та новітнім для медичного напряму. Академія $€$ першим медичним ВН3 на теренах України, який започаткував підготовку французькою мовою.

Набору студентів передувала значна підготовча робота, яка і досі триває, поглиблюється та вдосконалюється. Згідно $з$ розпорядженням по академії «Про організацію підготовчих заходів до проведення франкомовного навчання іноземних громадян», у Дніпропетровській медичній академії розпочато підготовку співробітників академії до викладання французькою мовою та методичної бази для навчання франкомовних студентів з 2018/2019н. р.

Курси мовної підготовки почали свою роботу у 2017 р. на постійній основі задля якісного і поглибленого вивчення нової мови викладання. Натепер навчання проходять 97 співробітників медичної академії. Викладання французької мови проводиться висококваліфікованими педагогами провідного Центру по вивченню французької мови «Alliance Française». Крім цього, викладачі академії також можуть використовувати бібліотеку «Alliance Française», відвідувати додаткові заняття на базі Альянсу, які присвячені поглибленню фонетики, граматики, розширенню знань за допомогою перегляду та розбору французьких фільмів, мультимедійних презентацій, спілкування з носіями французької мови, використовували спеціалізовані франкомовні сайти, доступ до яких є тільки в учнів Альянсу. Так, у червні 2018 р. до складання офіційного іспиту DELF/DALF з володіння французькою мовою рівнів A2, В1 та B2 на базі Центру по вивченню французької мови «Alliance Françаise» долучилися всі викладачі, які вивчали мову. Результатом ефективного навчання було отримання 61 сертифіката, що підтверджує знання. У жовні 2018 р. та у лютому 2019 р. ще 5 викладачів отримали відповідне підтвердження.

На початок навчального року було створено методичну базу матеріалів навчальних предметів 1-3 курсів за спеціальностями «Медицина» $\mathrm{i}$ «Сто- матологія». Йде робота над створенням термінологічних україно-англо-французьких словників та подальшого методичного забезпечення навчання, у тому числі спеціальності «Фармація». Для належної підготовки матеріалів та контролю їх виконання створено моніторингову групу франкомовного навчання в структурі ЦМК.

Беззаперечним індикатором методичного забезпечення студентів $\epsilon$ робота бібліотеки щодо створення книжкового фонду франкомовної навчальної літератури. Зазначимо, що у минулому році академією було придбано більш ніж 60 найменувань підручників французькою мовою. Крім цього, продовжується і реалізується робота над створенням власних підручників, навчальних посібників і методичних матеріалів для роботи з франкомовними студентами (натепер створено 17 власних навчальних та навчально-методичних посібників).

Ще однією вагомою передумовою започаткування новітнього франкомовного навчання була оцінка можливостей ВНЗ офіційними представниками та закладами Французької Республіки. 12 квітня 2018 р. до Дніпропетровської медичної академії завітала делегація Посольства Франції в Україні на чолі з Надзвичайним і Повноважним Послом Франції в Україні Ізабель Дюмон. Програма відвідування делегації Посольства Франції в Україні була достатньо насиченою. Були відвідані базові кафедри медичної академії, з яких починається навчання на 1 курсі в іноземних студентів. Крім цього, делегація Посольства Франції відвідала заняття 3 французької мови, на яких викладачі Дніпропетровської медичної академії опановують мову. Пані Посол Франції Ізабель Дюмон висловила велику зацікавленість щодо амбіційного проекту Дніпропетровської медичної академії підготовки студентів французькою мовою та пообіцяла всебічну підтримку у вирішенні всіх питань, поставлених керівництвом академії для впровадження вже в цьому році проекту франкомовного навчання студентів, що був започаткований у нашому навчальному закладі. Були обговорені питання щодо можливої співпраці з французькими медичними закладами та можливостей мовних і професійних стажувань викладачів академії у Франції.

Безпосередньо на початку 2018/2019 н. р. підготовка до франкомовного навчання також була проінспектована представниками Посольства Франції в Україні та Головою Асоціації франкомовних університетів і отримала високу оцінку. 
Для забезпечення якісної процедури набору франкомовних студентів приймальною комісією спільно з предметними комісіями було здійснено низку заходів, зокрема створено базу для проведення вступних випробувань для визначення як рівня мовної підготовки, так і знань із профільних предметів (хімія, біологія).

Цьогоріч на 1 курс було прийнято 78 іноземних студентів франкомовної форми навчання за спеціальностями «Медицина» і «Стоматологія». Заслуговує уваги питання досвіду та особливостей адаптації і викладання студентам нового напряму освіти, особливо на кафедрах 1 курсу.

Цей досвід вже має кафедра клінічної анатомії, анатомії та оперативної хірургії. На теперішній час на кафедрі працюють чотири викладачі, які володіють французькою мовою від рівня А2 до В2 згідно із сертифікованим загальноєвропейським іспитом DELF/DALF.

Однією з проблем, яка постала перед колективом кафедри, була відсутність підручників французькою мовою, які б відповідали Типовій програмі 3 дисципліни «Анатомія людини», розробленій для студентів вищих медичних закладів. Виявилось, що всі підручники французькою мовою з даної дисципліни для вищих медичних закладів в іноземних країнах мають іншу, клінічну спрямованість у викладанні. Тому в першу чергу, нагальним для колективу кафедри було створення навчального посібника з дисципліни французькою мовою, що відповідав би базовій типовій програмі з «Анатомії людини». При його складанні перед авторами також постало питання подання назв анатомічних структур згідно з медичною номенклатурою, яка використовується у франкомовних країнах, тому що латинські терміни там маловживані. Незважаючи на кропітку роботу, на початок навчання, завдяки плідній праці колективу авторів, такий навчальний посібник був створений та представлений франкомовним студентам-першокурсникам вже на першому занятті з «Анатомії людини». Крім цього, студенти мали змогу використовувати підручники, придбані бібліотекою і які є загальновживаними у європейських країнах (Frank H. Netter Atlas d'anatomie humaine; Richard L. Drake, A. Wayne Vogl, A. Mitchell, Fabrice Duparc, Jacques Duparc. Gray's anatomie pour les étudiants). Наступним методологічним етапом було створення «Словника анатомічних термінів» $з$ французькою номенклатурою анатомічних назв.
Основою методичної бази для кожного рівня освіти $є$ тестові завдання, що дають змогу швидко та ефективно оцінити рівень знань учнів. Ще одним щаблем з якісної підготовки спеціалістів були пошук франкомовних баз тестових завдань на сайтах медичних ВНЗ європейських країн та розробка таких, щоб відповідали клінічним завданням, які використовуються при складанні сертифікованих медичних іспитів в іноземних країнах. Основою слугувала база тестів, підготовлених для проходження незалежної державної атестації «Крок», складання якого є необхідним для отримання ліцензійного медичного диплома у нашій країні.

У допомогу викладачам до викладання та студентам до вивчення дисципліни французькою мовою були створені методичні розробки для кожного практичного, самостійного та лекційного заняття, розроблені презентації лекцій, створені робочі практикуми. Кафедра оснащена сучасним фантомномуляжним та комп'ютерними класами, якими студенти активно користуються як під час практичних занять, так і для позааудиторної роботи.

На кафедрі медичної біології, фармакогнозії та ботаніки навчаються франкомовні студенти першого курсу зі спеціальностей «Медицина» та «Стоматологія». Для підготовки студентів відповідно до тем робочих програм були створенні «Протоколи для практичних занять з медичної біології» французькою мовою, які затверджені на ЦМК. Використання таких протоколів значно полегшує самостійну підготовку студентів та містить стислий конспект із кожної теми занять. Написані «Методологічні розробки для практичних занять та самостійної роботи на французькій мові», що розміщені на сайті кафедри для вільного доступу студентів. Перекладено та видано окремим збірником тести бази «Крок 1» французькою мовою, що дозволяє студентам підготуватися до семінарських занять та екзаменів. Для більш інтенсивного засвоєння тестових завдань на кафедрі регулярно проводиться тестування в комп'ютерному класі, що значно спрощує як оцінювання знання тестів викладачем, так і самооцінювання своїх знань студентами.

Велика база навчальних макро- та мікропрепаратів кафедри використовується на практичних заняттях для формування навичок визначення паразитів людини та встановлення попереднього діагнозу, що підвищує зацікавленість першокурсників до майбутньої професії. Згідно з тематичними планами, розроблені мультимедійні лекції французькою 
мовою з використанням комп’ютерних технологій, які містять навчальні фільми французькою мовою 3 тем лекцій та практичних занять для поглиблення знань із медичної біології.

Франкомовні студенти першого курсу активно залучаються до роботи студентського наукового гуртка, вони готують доповіді та міні-презентації за обраними темами. За виникнення питань консультуються з викладачами кафедри медичної біології згідно із затвердженим графіком. Така робота розвиває у студентів вміння пошуку та систематизації матеріалу, вони вчаться представляти матеріал у стислій та зрозумілій формі. Участь франкомовних студентів у роботі наукового гуртка дозволяє підвищити їх зацікавленість до навчання та розширює їх кругозір і $є$ високим мотивуючим фактором у засвоєнні базових доклінічних дисциплін.

Висновки. Створені на кафедрах умови освітнього процесу сприяють особистісному розвитку франкомовних студентів, їх майбутнього фаху, фор-

\section{Список літератури}

1. Кушнір I. М. Сутність і структура соціокультурної компетентності іноземних студентів у контексті міжкультурної комунікації / I. М. Кушнір // Мова і культура : наук. журнал. - К. : Видав. дім Дмитра Бураго, 2009. Вип. 12, т. III (128). - С. 54-58.

2. Туркот Т. І. Педагогіка вищої школи / Т. І. Туркот. К. : Кондор, 2011. - 628 с.

\section{References}

1. Kushnir, I.M. (2009). Sutnist i struktura sotsiokulturnoi kompetentnosti inozemnykh studentiv u konteksti mizhkulturnoi komunikatsii [Essence and structure of sociocultural competence of foreign students in the context of intercultural communication]. Mova i kultura-Language and Culture, 12, 3(128), 54-58 [in Ukrainian].

2. Turkot, T.I. (2011). Pedahohika vyshchoi shkoly [Pedagogy of high school]. Kiyv: Kondor [in Ukrainian]. муванню професійних важливих якостей, компетенцій, знань та вмінь. Використання різнобічного підходу навчання в навчальному процесі сприяє поєднанню навчальної діяльності академічного типу 3 майбутньою професійною діяльністю. Описана модель викладання дисциплін для студентів франкомовних груп в освітній практиці українського медичного ВНЗ є засобом підвищення педагогічної майстерності викладачів, ефективності роботи самих студентів у досягненні більш високих освітніх результатів.

Дніпропетровська медична академія - перший медичний ВНЗ на території України, який впроваджує навчання французькою мовою, є прикладом для інших медичних освітніх закладів. Франкомовне навчання - це ексклюзивна пропозиція на ринку послуг медичної освіти в Україні, враховуючи значну конкуренцію серед медичних ВНЗ України за англомовних студентів.

3. Яцишина О. Методичні основи формування соціокультурної компетенції іноземних студентів-медиків в умовах реалізації Болонського процесу / О. Яцишина // Тенденції розвитку вищої освіти в Україні: європейський вектор. Ч. 3. - Ялта, 2012. - С. 203-207.

3. Yatsyshyna, O. (2012). Metodychni osnovy formuvannia sotsiokulturnoi kompetentsii inozemnykh studentiv medykiv $\mathrm{v}$ umovakh realizatsii Bolonskoho protsesu [Methodical bases of formation of sociocultural competence of foreign medical students in conditions of implementation of Bologna process]. Tendentsii rozvytku vyshchoi osvity $v$ Ukraini: yevropeiskyi vector - Trends in Higher Education Development in Ukraine: European Vector. Yalta [in Ukrainian]. 